\title{
The impact of poor governance on water and sediment quality: a case study in the Pitimbu River, Brazil
}

\author{
LUCIO MOREIRA ${ }^{1}$, JAN ADAMOWSKI ${ }^{2}$, SUSAN GASKIN ${ }^{3} \&$ \\ ANDREA SARAIVA ${ }^{1}$ \\ 1 DEC/CT/UFRN, Campus Universitário, Lagoa Nova, Natal, RN, 59082-970, Brazil \\ $\underline{\text { lucio@,ct.ufrn.br }}$ \\ 2 Department of Bioresource Engineering, McGill University, 21111 Lakeshore Road, Sainte-Anne-de-Bellevue, \\ QCH9X 3 V9, Canada \\ 3 Department of Civil Engineering, McGill University, 817 Sherbrooke Street West, Montreal, QC H3A 0C3 Canada
}

\begin{abstract}
Applying a collaborative approach under a power-sharing institutional structure, coupled with a shift in paradigms, sustainable water resources management often requires political-institutional reform to achieve its goals. Most of Brazil's river basins are subject to rapid urbanization; however, basin stakeholders generally lack sufficient institutional capacity to address the attending water resource issues. Subject to urbanisation, the Pitimbu River basin supplies potable water to approximately 280000 people in Brazil's Natal region. This study investigated how current institutional models influence both water management and fluvial contamination by metals. Sediment samples collected at eight sites along the river revealed elevated levels of $\mathrm{Pb}, \mathrm{Fe}, \mathrm{Al}, \mathrm{Ni}$ and $\mathrm{Zn}$, whose sources were linked to industries, vehicles, as well as agricultural and construction wastes. Aluminium enrichment of surface waters was mainly linked to inadequate sanitation infrastructure. In light of this, the region's poor institutional capacity must be addressed through institutional reform, including a new management structure open to public collective water management planning. In so doing, Brazil's water policies should acknowledge capacity building as a critical element of institutional reform.
\end{abstract}

Key words water governance; Pitimbu River; urbanization; land use management; institutional reform; institutional capacity

\section{INTRODUCTION}

Sustainable water resources management implies a collaborative approach and power-sharing institutional structure. The global rise in water supply and quality issues have challenged water institutions to reconsider traditional practices, and adopt a more functional and power-sharing framework, while promoting a collective participatory process effective in addressing social objectives (Huitema et al. 2009).

Over the years, top-down state-centric water governance models have proven to be rather ineffective in addressing societal and environmental issues (Hajer and Wagenaar 2003). Conversely, water sector reform has the potential to invoke multi-institutional arrangements capable of reducing the distance between managers and the public, promoting collaboration and increasing the legitimacy of decision-making (Karkkainem 2004, Ostrom 2005). Moreover, public participation in environmental management renders the process more democratic, leads to greater engagement and increases the accountability of the decision-makers (Van der Kerkhof and Huitema 2004, Pahl-Wostl 2002).

In Brazil, public participation in water resources management is not widespread, and its implementation would necessitate a review and transformation of the current managerial and administrative framework. In addition, an integrated perspective of water and land use management must be considered.

\section{Urbanization and the challenge of management}

Urbanization modifies environmental parameters and fluvial regimes to such an extent as to affect sedimentation dynamics within a catchment (Taylor and Owens 2009). In urbanized river basins, sediment sources arise mainly from paved roads, construction, industrial sources, and wastewater. Sediments entering urban rivers play an important role in contaminant transfer and water quality. In most cases, they are enriched by metal, nutrients and organic pollutants originating from roads and poor sanitation infrastructure (Owens et al. 2005, Owens 2008, Viers et al. 2009). Indeed, chemical pressures on fluvial systems are manifested as increasing pollution concentration rates (Horowitz 
and Stephens 2008, Laidlaw and Filipeli 2008). In this study, fluvial sediment studies were used to assess heavy metal contamination levels in the environment.

In most Brazilian metropolitan regions, water and sediment degradation are the result of poor master plans, ineffective instruments of regulation implementation, and inadequate sanitation infrastructure. To try and help address the above issues, the following research questions were addressed in this paper:

- Determine the level of sediment contamination by metals in the Pitimbu River basin.

- Explore the links between water and sediment contamination by metals and poor institutional capacity at the local level.

- Explore how the management approach or paradigm reflects the institutional arrangement.

The objective of this study was therefore to investigate how approaches to basin management and governance in the the Pitimbu River basin influence both the land-use configuration and the contamination of the fluvial system in the Pitimbu River basin by heavy metals.

\section{MATERIALS AND METHODS}

\section{Study area}

Located in the eastern portion of Rio Grande do Norte State (Brazil), the Pitimbu River basin drains an area of $107 \mathrm{~km}^{2}$, spans three municipalities in the Natal metropolitan region (Macaíba, Parnamirim and Natal) and supplies potable water to approximately 280000 people in the Natal region. The basin lies over sedimentary rocks as well as movable dunes, paleo-dunes and Quaternary sand deposits. Water discharge at site 2, located $6.49 \mathrm{~km}$ upstream from the water treatment plant, ranged between $0.62 \mathrm{~m}^{3} \mathrm{~s}^{-1}$ (end of the dry season, December 2007) to a maximum flow rate of 10.6 $\mathrm{m}^{3} \mathrm{~s}^{-1}$ (June 2008). Urbanization has adversely affected the fluvial system. Over the years, land use and settlement have occurred with little consideration for environmental sustainability or existing regulations, causing fluvial degradation and contamination by toxic substances. Water and sediment degradation has its origins in both point and non-point sources: residential wastewater, livestock and construction residues, road-deposited sediment inputs, pesticides, and channel erosion. Satellite image analysis of settlements within the basin indicate that lowland reaches have been subject to increasing settlement. Using Google Earth ${ }^{\circledR}$ images, land use types were identified and their relative areas calculated: residential, $17.6 \%$; forested, $40 \%$; initial stage of urban development, $12.9 \%$; agriculture, $18.5 \%$; rural conglomerates, $2.1 \%$; military area, $6.4 \%$; and industrial area, $2.2 \%$.

\section{Management experience and heavy metals analysis}

Founded by the state government to deliberate local water management policy, the Pitimbu River Basin Organization (RBO) is a local collective organism composed of public and private representatives, NGOs and universities. However, experience has demonstrated the irrelevancy of the RBO in the decision-making process. This situation is in part attributable to: (a) a top-down bureaucratic administrative model, (b) a disorganized managerial arrangement involving municipal and state levels, (c) a fragmented management perspective, and (d) the poor technical capacity of some RBO members.

At the national level, Brazil's experience in water management is relatively recent. Despite an effort to implement a nationwide management policy, contrasting management histories throughout the country and poor local institutional capacity have prevented a successful outcome.

A remarkable step in Brazil's water management efforts was the enactment of National Law 9433/97, which instituted a national water resources policy and created both the national water resources system and national water agency, ANA (SRH 2006). The ANA supervises the application of the law and has jurisdiction over the management of inter-state river watersheds. Given the regional diversity in institutional capacity which exists, a national administration should consider local specificities and assist through local capacity building initiatives.

In developed regions, the institutional capacity and engagement of stakeholders facilitates sustainable water management, where funding resources are applied in infrastructure and social 
training. Conversely, in poor regions institutional capacity is lacking and water policies are politically centralized. Most of the actors involved are resistant to shifts in the governance structure.

Experience in the Pitimbu River basin demonstrates that water must be considered through an integrated, multi-sectorial approach. At the local level, a disorganized land use policy disregards environmental rules and adversely impacts water quality and ecosystems. Indeed, it reinforces a situation of unbalanced political power at the expense of public participation and ecological needs. Because land use rules are not judiciously applied, inadequate planned settlements can crop up in environmentally protected areas. In addition, there is little public awareness of ecological concerns, such that: (a) there seems to be an institutional distance between the local community and decisionmakers, lawmakers and other practitioners; (b) ecological concerns are not prioritized; (c) engineering works are not designed to be preventive; (d) engineering solutions rarely take into account sustainability issues, and managerial planning is lacking; and (e) public engagement in collective planning is not widespread. Because public awareness is weak, near site solid waste disposal occurs in some areas despite the existence of a collection service.

Moreover, Brazil's national water resources policy, locked into a framework imposed by state administrative autonomy, leaves administrative gaps between levels. Such insights lead to some concerns regarding the current national framework. How feasible is it to deal with regional diversity in the face of poor local institutional capacity? One must address the question as to what extent a national response can be effective in light of poor state governance.

Water and stream bed sediment samples were collected at eight sites along the river bed. Collection campaigns were performed between September 2011 and February 2012, spanning the dry season. Riverbed sediment samples $(0-0.05 \mathrm{~m})$ were obtained using a Van Veen dredge. Collected sediment samples were stored in $500 \mathrm{~g}$ PE containers and frozen at $-5^{\circ} \mathrm{C}$. Prior to the assessment of contaminant loads, samples were thawed in a stove at $80^{\circ} \mathrm{C}$ over a 24 hour period. Dry sediment was disaggregated and sieved (\#63 sieve). A representative sediment sample was extracted for use in an acid digestion procedure (method 3050B-USEPA). The digestion solution was filtered through Whatman filter paper and diluted in $100 \mathrm{ml}$ of distilled water. The solution was submitted to FAAS analysis using a spectrometer (model AA240 VARIAN ${ }^{\circledR}$ ). The following metals were analysed: aluminium, iron, cadmium, copper, lead, nickel and zinc.

\section{RESULTS}

The longitudinal distribution of metal concentrations in the surface water and sediment of the Pitimbu River are shown in Fig. 1(a) and (b), respectively, where horizontal lines represent the metals' background levels. Background levels were taken on the basis of sediment analyses of samples collected on the most upstream sites near headwater areas during the dry season (between October 2011 and February 2012). Cadmium and copper were not detected in the sediment. Cadmium, copper, lead, nickel and zinc were not detected in the water. Concentration values were calculated as mean estimates in a transverse cross-section. An assessment of the impact of metals on the fluvial system was made on the basis of pre-anthropogenic conditions as background levels.

A metal enrichment was observed as the river drains vast areas occupied by residential, agricultural and industrial uses. Such enrichment was not uniform but varied along the river length as a function of the metal, reflecting the effect of contamination from different point and non-point sources. Road-deposited sediment stored on road surfaces supplies inputs to the river at many locations. A comparison of the longitudinal metal concentrations revealed that metal enrichment tends to coincide with points or stretches affected by human activity.

Maximum enrichment ratios in sediment revealed a high degree of contamination for the majority of the metals under investigation: lead, iron, aluminium, nickel and zinc $(1100 \times, 110 \times$, $40 \times, 100 \times$ and $15 \times$, respectively). Iron and lead enrichment ratios were especially high at sites 6 (110× and $1100 \times$, respectively) and 7 (55× and $1000 \times$, respectively) relative to background levels. Site 6 probably reflects the effect of contaminant inputs from vehicles because it is located near a highway subjected to heavy traffic conditions. Site 7 metals enrichment is probably the result of the poor local roadway infrastructure. The iron enrichment ratio, observed at all monitoring sites, is 

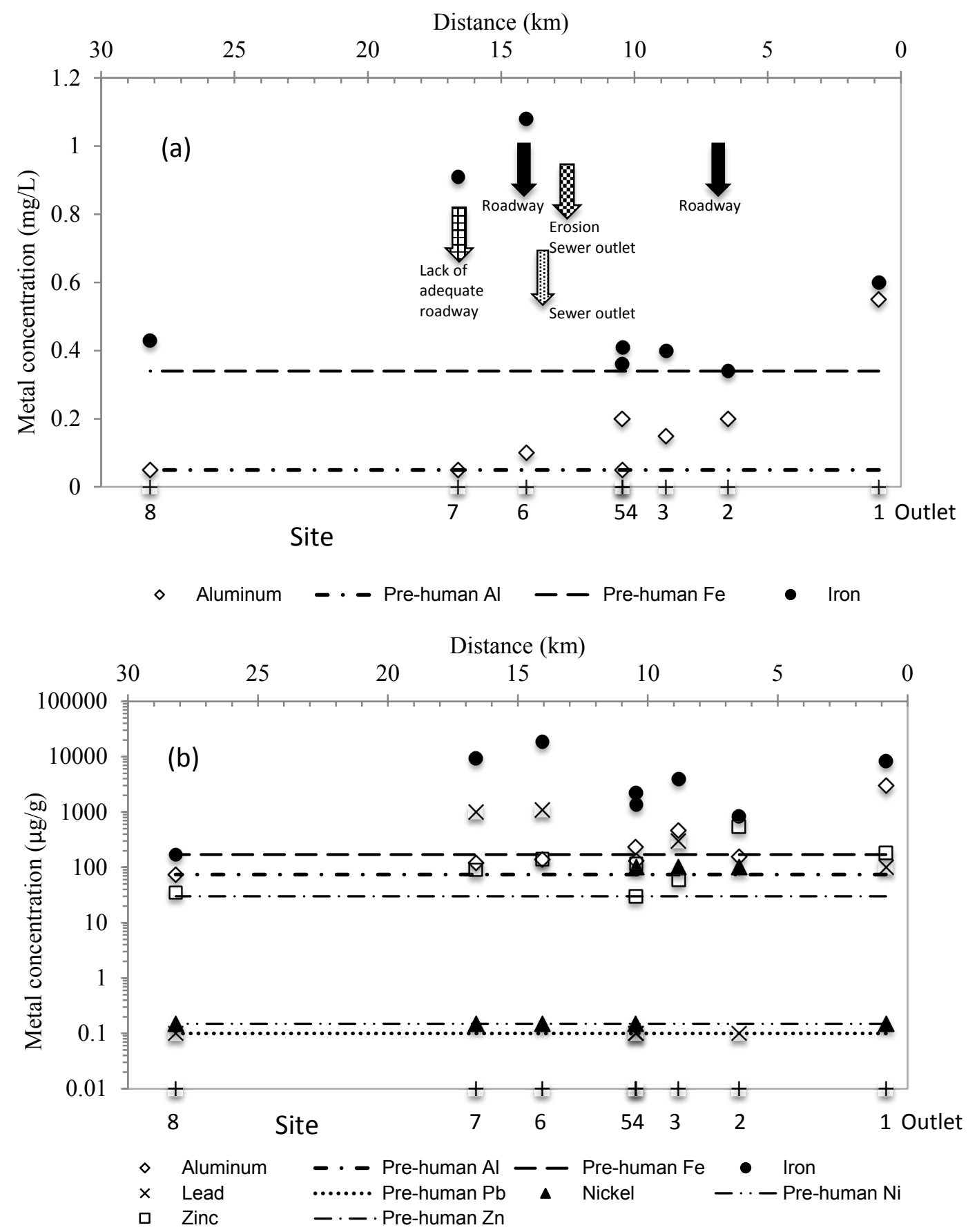

Fig. 1 Metal concentration levels in water (a) and in sediment (b) at eight sites on the Pitimbu River, Brazil. Horizontal lines indicate metals background levels.

likely due to a number of different input sources. The river's headwater sediment samples revealed concentrations of iron, aluminium and zinc (171, 74 and $35 \mu \mathrm{g} / \mathrm{g}$, respectively). Because river-bed sediment samples were collected during the dry season $(0-5 \mathrm{~cm})$ they represented the inputs of surrounding metal sources over previous years.

In the surface water, iron concentrations were especially high in sites 6 and 7 (2.4× to $2.7 \times$ background levels, respectively) and coincide with levels in the sediment. This also reflects the effects of the river hydrology during periods of low water discharge rates. Aluminium concentrations in the surface water revealed an increasing trend as the river drains downstream. This probably reflects non-point inputs from underwater flow through the un-confined aquifer. 
From these results it is evident that poor governance has led to the Pitimbu River's sediment and surface water contamination over time. This governance structure has failed to ensure a sustainable potable water supply because the land use and settlement decision-making process is centralized and public engagement is poor. In addition, the collective political perspective seems to be poor (Beierle and Cayford 2002).

The information developed in this study can serve to inform decisions as to how to respond to these problems:

- An adequate water management plan considering a broad application of integrated and adaptive water management concepts in the basin must consider the social-ecological system.

- A collective planning water management process is critical to design and implement a management policy (Molle et al. 2010).

- A collective water perspective, where people can collaboratively work out their individual preferences and differences is particularly relevant. Indeed, it implies that national, state and municipalities build a collaborative approach, led by the national administration.

- Institutional and ecological system relationships and feedbacks must be modelled and analysed. This process should involve natural resources, institutional arrangements, public infrastructure, and past and current human activities.

- The nature of institutional structures, along with an understanding of system functions and interactions is critical to institutional capacity building (Kühl 2004). Governmental institutions must be enhanced to deal with the complexity of the situation and made aware of the fact that water is a management-based problem. Transparency and accountability in the decision-making process should be encouraged.

\section{CONCLUSIONS}

This study investigated how the Pitimbu River's basin management approach influences the fluvial system's contamination by metals. It was found that:

- Observed levels of metal enrichment in fluvial sediment (lead, iron, aluminium, nickel and zinc) and water (iron and aluminium) indicate that the current institutional model fails in ensuring potable water in a long term or sustainable manner.

- The institutional structure is disorganized, bureaucratic and fragmented. Public participation in decision-making is lacking.

- A sound political-institutional reform founded on a participatory approach should be implemented.

- An institutional reform must address the institutional capacity at the local level. This implies a new managerial structure that stimulates public collective water planning.

- The Brazilian water management policy should take capacity building at the local level as a critical element in institutional reform.

Acknowledgements The Conselho Nacional de Desenvolvimento Cientifico e Tecnológico / MCT / Brazilian Government [236410/2012-1] and McGill University supported this research work.

\section{REFERENCES}

Beierle, T. C. and Cayford, J. (2002) Democracy in Practice: Public Participation in Environmental Decisions. Resources for the Future Press.

Hajer, M. A. and Wagenaar, H. (eds) (2003). Deliberative Policy Analysis - Understanding Governance in the Network Society. Cambridge University Press.

Horowitz, A. J. and Stephens, V. C. (2008) The effects of land use on fluvial sediment chemistry for the conterminous U.S. results from the first cycle of the NAWQA Program: trace and minor elements, phosphorus, carbon, and sulphur. Science Total Environment 400(1-3), 290-314, doi: 10.1016/j.scitotenv.2008.04.027.

Huitema, D., et al. (2009) Adaptive water governance: assessing the institutional prescriptions of adaptive (Co-) management from a governance perspective and defining a research agenda. Ecology and Society 14(1), 26, http://www.ecologyandsociety.org/vol14/iss1/art26/ (23 October 2013).

Karkkainen, B. C. (2004) Post-sovereign environmental governance. Global Environmental Politics 4(1), 72-96, doi:10.1162/152638004773730220. 
Kühl, S. (2004) Fashions in development cooperation. Capacity building and capacity development as new models for development aid organizations. http://www.cgiar-ilac.org/files/Kuhl Fashions Development Cooperation.doc (23 October 2013).

Laidlaw, M. A. S. and Filipeli, G. M. (2008) Resuspension of urban soils as a persistent source of lead poisoning in children: a review and new directions. Applied Geochemistry 23(8), 2021-2039, doi: 10.1016/j.apgeochem.2008.05.009.

Molle, F., Wester, P. and Hirsch, P. (2010) River basin closure: processes, implications and responses. Agricultural Water Management 97(4), 569-577, doi: 10.1016/j.agwat.2009.01.004.

Ostrom, E. (2005) Understanding Institutional Diversity. Princeton University Press.

Owens, P. N. (2008) Sediment behaviour, functions and management in river basins. Sustainable Management of Sediment Resources, 4: 1-29, doi:10.1016/S1872-1990(08)80003-7.

Owens, P. N., et al. (2005) Fine-grained sediment in river systems: environmental significance and management issues. River Resources Applications 21(7), 693-717, doi: 10.1002/rra.878.

Pahl-Wostl, C. (2002) Towards sustainability in the water. The importance of human actors and processes of social learning. Aquatic Sciences, 64(4), 394-411. doi: 10.1007/PL00012594.

Semple, E. C. (1911) Influences of Environment. H. Holt \& Co.

SRH (2006) Plano Nacional de Recursos Hídricos: síntese executiva, Secretaria de Recursos Hídricos, Ministério do Meio Ambiente, Brasília, Brasil. http://www.integracao.gov.br/c/document library/get file?uuid=c37feae3-8169-4049-900be8160661 f541\&groupId=66920 (23 October 2013).

Taylor, K. G. and Owens, P. N. (2009) Sediments in urban river basins: a review of sediment-contaminant dynamics in an environmental system conditioned by human activities. J. Soils Sediments 9(4), 281-303, doi: 10.1007/s11368-009-0103-z.

Van der Kerkhof, M. and Huitema, D. (2004) Public Participation in river basin management. A methodological perpective. In: Information to Support Sustainable Water Management. From Local to Global Levels, 141-148, Lelystad, RIZA.

Viers, J., Dupre, B. and Gaillardet, J. (2009) Chemical composition of suspended sediments in world rivers: new insights from a new database. Science Total Environment 407(2), 853-868, doi: 10.1016/j.scitotenv.2008.09.053. 